\title{
Differential gene expression of pectin esterase and changes in pectin during development and ripening stages of fruit in selected cultivars of banana
}

\author{
Nouman Rashid SIDDIQUI ${ }^{*}$ (D), Aish MUHAMMAD², Muhammad Ramzan KHAN², Ghulam Muhammad ALI $^{2}$, \\ Talat MAHMOOD ${ }^{3}$, Armghan SHAHZAD², Saqib JABBAR ${ }^{1}$
}

\begin{abstract}
Pectin is a very important ingredient in food processing. The present study was designed to find out the changes taken place in pectin content during development and ripening phases of banana fruit. The expression of gene (pectin esterase) was also observed during development and ripening. Five exotic cultivars namely William, Brazilian, G-Naine, Basrai and Pisang were selected for this study. Sampling were carried out after every 2 weeks during development and there was 6 sampling stages (from emergence to harvesting stage). After harvesting the fruit of all cultivars were subjected to natural ripening in the lab and sampling during ripening were carried out according to the colour changes in the fruit skin. 5 ripening stages were studied. Hence total number of 11 stages were studied during development and ripening. The sequence of pectin esterase were obtained from NCBI, primers were designed and procured. RNA was extracted from each cultivar and expression analysis of pectin esterase was carried out. It was found that the expression of gene is variable during the development and the ripening stages in each cultivar. Similarly, the pectin content were also significantly variable during development and ripening of fruit. The variation was also found among the cultivars. It was concluded that unripe banana have more pectin content then ripe banana and the pectin content of the fruit is associated with expression of the gene.
\end{abstract}

Keywords: pectin; pectin esterase; gene expression; development and ripening; banana.

Practical Application: Banana pectin particularly from early stages (unripe) of development can be extracted and utilized in various food preparations.

\section{Introduction}

All physiological and biochemical variations that occur during ripening of fruit are controlled by the synchronized genes expression. Enzymes encoded by these genes then contribute to biochemical and physiological deviations.

In normal ripening, expression of specific gene is essential part. During climacteric fruit ripening the example is the de novo synthesis of enzymes contributing in the autocatalytic burst of ethylene (Liu et al., 2016). Many metabolic pathways are dependent on specific expression of genes. Several physiological variations linked to ripening have been dependent on some genes of enzymes. On the basis of previous studies on tomato, there already exists knowledge regarding the genes responsible in the very vital physiological variations, like the cell wall loosening, buildup of sugars, synthesis of pigments and aromatic compounds during ripening (Li et al., 2019)

Pectin is produced into the cell wall in an extremely methylesterified arrangement and pectin methylesterases (PMEs) gene is responsible to subsequently de-esterify it (Zega \& D'Ovidio, 2016). PMEs may also be responsible in defining the extent to which demethylated polygalacturonans are available by PGs (Polygacactunases) for degradation, releasing galacturonic acid or oligogalacturonate, and the availability carboxylic groups of homogalacturonan for Calcium $\left(\mathrm{Ca}^{2+}\right)$ binding leads to the formation of supramolecular assemblies and gels. These gels believed to affect the mechanical characteristics of the cell wall and gives firmness to the wall (Wang et al., 2018). In most fruit, PME is expressed before ripening and have little role in fruit softening but effect integrity of tissues (Kohli et al., 2015)

Being complex and highly diverse in structure, role of pectin is not only limited to the biological and physiological functions, but it has tremendous potential and contributes substantially in other applications ranging from food processing to pharmaceuticals. Pectin is a water-soluble fiber and used in various foods as emulsifier, stabilizer, gelling, and thickening agent. Pectin is widely used in industry as emulsifier, stabilizer, gelling agent and also used for food packaging. (Ngouémazong et al., 2015). This study has been designed to find out the expression of pectin esterase at different levels of development and ripening in some exotic cultivars of banana in Pakistan. No study has been previously carried out in these cultivars for these parameters from emergence to over ripening stages. The purpose of the study is to assess at which stage of development, the expression of pectin esterase is higher or lower. The outcome is expected to be useful for further studies at molecular level like over regulation, inhibition or control of pectin esterase expression 
at any particular stage. unripe banana is not being presently used for pectin extraction and utilization in food processing industry. One of the purpose of the study is to generate data and create awareness regarding pectin content and its changes during development and ripening in selected cultivars

\section{Material and methods}

\subsection{Plant material and growing conditions}

Five banana cultivars introduced and being grown in Pakistan were selected. That included Williams', Basrai, Grand-Naine (G-Naine), Pisang and Brazilian planted through tissue culture technique at Tandojam, Pakistan were used in this research study. Samples of all cultivars were dispatched to National Agricultural Research Centre, Islamabad, Pakistan for analysis. The samples were brought to lab in stages after every 2 weeks from emergence of fingers till harvesting and then banana were allowed to ripen and sampling was done during ripening stages according to the color changes. Total number of 11 stages was analyzed including developmental and ripening stages. Details of these stages are given in Table 1.

\subsection{RNA extraction}

Different protocols were followed for RNA (Ribonucleic acid) extraction including, Trizol methods, RNA extraction kit (Fermentas Life Sciences), CTABI (Cetyl trimethylammonium bromide), CTABII and CTAB-LiCl (Lithium Chloride) based procedures. Best results with good quality and quantity of RNA was found through improved CTAB-LiCL method with slight modification. This method is primarily based on adopting Improved CTABII method and hot borate method of Wan \& Wilkins (1994) and Yao et al. (2005).

\subsection{Measurement of the quality and quantity of RNA}

Quality of extracted RNA from Banana fruit was assessed on $1.5 \%$ agarose gels. The gels were run for 25 minutes and then photographed via gel documentation system. The RNA was also quantified using Thermo scientific Nanodrop spectrometer to confirm good quantity and quality RNA is available for further analysis.

\subsection{Gene selection and primer designing}

For the expression analysis and to find out the role of Pectin esterase gene in fruit ripening, responsible for pectin synthesis were selected from literature. Actin gene was employed as a reference gene (control) for the accuracy. Nucleotide sequences of the pectin esterase and Actin were obtained from National Center of Biotechnology Information (NCBI) database with accession No. (GenBank: AB022041.1 for actin) and (GenBank: Y07899.1 for Pectin esterase). The forward and reverse primers were designed from the sequences of 20 bp using online Primer 3 online package and given below a First strand cDNA synthesis

\subsection{Complementary DNA (cDNA) synthesis}

Complementary DNA (Deoxyribonucleic acid) or cDNA was synthesized from mRNA (messenger RNA) in a reaction catalyzed by reverse transcriptase. The mRNA was converted to cDNA because its instability and to avoid intron regions of gene. Best quantity mRNA with 190 OD (Optical Density) and nucleotide concentration ranging nearly $800 \mathrm{ng} / \mu \mathrm{L}$ (nano gram per micro litre) was used for cDNA synthesis. Gene specific primer (reverse primer) was used instead of oligodt primers.

A total of $20 \mu \mathrm{L}$ reaction mixture was prepared for cDNA synthesis using Super Script ${ }^{\oplus}$ Double-Stranded cDNA Synthesis Kit (Thermo Fisher Scientific). All the reagents used in the reaction were kept in ice. Master Mix was prepared in a nuclease free micro centrifuge tube containing $4 \mu \mathrm{L}$ of RNA, $1 \mu \mathrm{L}$ of reverse primer and $9 \mu \mathrm{L}$ of double distilled water. Master Mix was prepared for each sample, in case where RNA was not of good quality $(\sim 600 \mathrm{ng} / \mu \mathrm{L})$ then the volume of RNA was adjusted. Master Mix was incubated at $65^{\circ} \mathrm{C}$ (degree Centigrade) for five minutes to denature RNA and then the reaction was placed on ice for two-three minutes. In the following step, when chilled other reagents were added $1 \mu \mathrm{L}$ of Reverse transcriptase enzyme, $1 \mu \mathrm{L}$ of $10 \mathrm{mM}$ (Mili Mole) dNTPs (deoxyribonucleotide triphosphate) and $4 \mu \mathrm{l}$ of $5 \mathrm{X}$ reaction buffer was added to each tube. The mixtures were mixed by vortex and spin slowly to bring all contents into the bottom of the tube. And taken back to PCR (Polymerase Chain Reaction) for additional two stages transcription and final extension.

\subsection{Multiplex semi quantitative PCR}

Multiplex PCR analysis was carried out using two primers instead of one used in general purposes. The primer pairs consisted of one pair for the desired gene and the second one is used as a reference or housekeeping gene (Actin gene) to see accuracy of experiment. Master mixture was prepared containing, $2.5 \mu \mathrm{L}$ of cDNA, $3 \mu \mathrm{L}$ (Magnesium Chloride) $\mathrm{MgCl}_{2}, 1 \mu \mathrm{L}$ of $10 \mathrm{mMdNTPs}$, $1 \mu \mathrm{L}$ of Primer 1-F (Forward), $1 \mu \mathrm{L}$ of Primer 1- R (Reverse), $1 \mu \mathrm{L}$ of Actin gene- F, $1 \mu \mathrm{L}$ of Actin gene- R, $5 \mu \mathrm{L}$ of Taq buffer, $0.5 \mu \mathrm{L}$ of Taq (Thermus aquaticus) enzyme and the final volume was raised to $20 \mu \mathrm{L}$ with PCR water. For standard PCR, the following program was run in initial denaturation phase was $95^{\circ} \mathrm{C}$ for $5 \mathrm{~min}$, followed by 37 cycle of $94^{\circ} \mathrm{C}$ for 1 minute denaturation, the annealing temperature was set for each individual primer. The extension stage was $68^{\circ} \mathrm{C}$ for $1 \mathrm{~min}$. then followed by the

Table 1. Different Stages of development and ripening.

\begin{tabular}{|c|c|c|c|c|c|c|c|c|c|c|}
\hline \multicolumn{11}{|c|}{ Physiological stages } \\
\hline 1 & 2 & 3 & 4 & 5 & 6 & 7 & 8 & 9 & 10 & 11 \\
\hline $\begin{array}{l}\text { Unripe-1 } \\
\text { (2 weeks) }\end{array}$ & $\begin{array}{l}\text { Unripe-2 } \\
\text { (4 weeks) }\end{array}$ & $\begin{array}{l}\text { Unripe- } 3 \\
\text { (6 weeks) }\end{array}$ & $\begin{array}{l}\text { Unripe- } 4 \\
\text { (8 weeks) }\end{array}$ & $\begin{array}{l}\text { Unripe- } 5 \\
\text { (10 weeks) }\end{array}$ & $\begin{array}{c}\text { Ripe-1 } \\
\text { (All green) }\end{array}$ & $\begin{array}{c}\text { Ripe-2 } \\
\text { (Green with } \\
\text { yellow traces) }\end{array}$ & $\begin{array}{l}\text { Ripe-3 (More } \\
\text { green than } \\
\text { yellow) }\end{array}$ & $\begin{array}{l}\text { Ripe-4 (More } \\
\text { yellow than } \\
\text { green) }\end{array}$ & $\begin{array}{c}\text { Ripe-5 } \\
\text { (all Yellow) }\end{array}$ & $\begin{array}{c}\text { Ripe-6 } \\
\text { (yellow with } \\
\text { black spot) }\end{array}$ \\
\hline
\end{tabular}


final extension were $68^{\circ} \mathrm{C}$ for $7 \mathrm{~min}$. Block temperature of the PCR machine was kept $105^{\circ} \mathrm{C}$ and terminated the reaction by $4{ }^{\circ} \mathrm{C}$ for short-term storage.

\subsection{Determination of pectin content}

Pectin content was analysed using a method described by Castillo-Israel et al. (2015). Homogenized banana pulp powder was added to each of $0.50 \mathrm{~N} \mathrm{HCl}$ (Hydro chloric acid), $\mathrm{pH} 1.5$ and $0.50 \mathrm{~N}$ citric acid, $\mathrm{pH}$ 1.7. These were then heated with continuous stirring at $90 \pm 5{ }^{\circ} \mathrm{C}$ in a stirring hot plate for $1,2,3$ and 4 hours. The solution was then cooled and filtered through an ordinary screen with 1-mm (Milli meter) mesh size with two-layer cheesecloth. The filtrate was collected and then added with twice its volume of absolute ethanol. The precipitates were filtered through a mira cloth. The residue was oven dried for 2 days at $55^{\circ} \mathrm{C}$ and then weighed. The pectin yield was calculated using the Equation 1:

Pectin yield $(\%) \mathrm{db}=\frac{\mathrm{P}}{\mathrm{Bi}} \times 100$

Where $\mathrm{p}$ extracted pectin in gram

$\mathrm{Bi}$ weight of alcohol-insoluble-residue in gram

\subsection{Statistical analysis}

All the numerical data obtained were subjected to statistical analysis using complete randomized design through statistix software (Version 8.1, Analytical Software, USA).

\section{Results and discussion}

\subsection{Pectin esterase transcripts exhibit variable expression in different development and ripening stages}

The expression of Pectin Esterase (PE) is related with the accumulation of pectin in the fruit pectin is very important ingredient of commercial value. Visual observation of PE expression in all the cultivars revealed that expression either remained the same or increased as development and ripening progressed (Figure 1). The expression pattern however is variable among the cultivars. In William and G-naine, medium expression was observed at stage 4 which remained medium till $7^{\text {th }}$ stage, became strong at stage 8 and 9 and then very strong at stage 11 . Strong expression was observed at stage 4 in Basrai and G-naine which remained strong till stage 9 in G-naine and stage 10 in Basrai. Very strong expression was observed at stage 11 in Basrai and at stage 10 and 11 in G-naine. In pisang, low expression

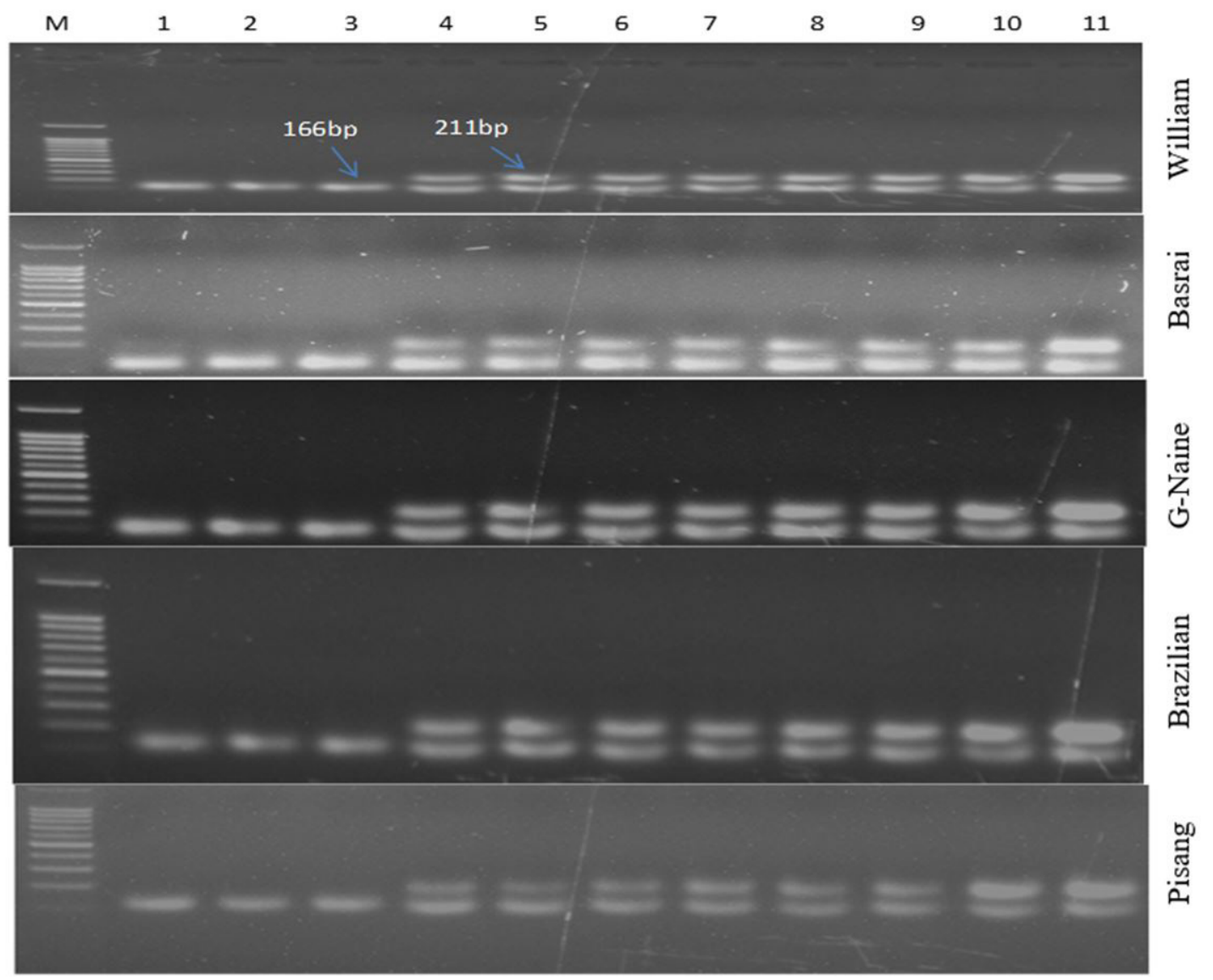

Figure 1. Expression of Pectin Esterase gene in banana cultivars at different stages of development and ripening- Semi quantitative RT-PCR was performed using Actin gene as endogenous (Lower band). M Stands for 1 KB Leader; No. 1 to 11 indicates stages of development and ripening; 166 bp Actin bands; 211 bp Pectin esterase bands. Arrows represent the amplicon size in base pair of actin gene (lower band) and pectin esterase gene (upper band). 
was found from stage 4 to stage 6 , medium expression from stage 7 to 9 and strong expression from stage 10 to 11 (Table 2).

It was observed that in all cultivars the expression did not decrease or dropped at any stage of development and ripening. It can be evident from the values of pectin that continuously decreased as the expression increased. Pectin is produced into the cell wall in an extremely methylesterified arrangement and pectin methylesterases (PMEs) gene is responsible to subsequently de-esterify it (Zega \& D’Ovidio, 2016).

PEs may also be responsible in defining the extent to which demethylated polygalacturonans are available by PGs for degradation, releasing galacturonic acid or oligogalacturonate, and the availability carboxylic groups of homogalacturonan for $\mathrm{Ca}^{2+}$ binding leads to the formation of supramolecular assemblies and gels. These gels believed to affect the mechanical characteristics of the cell wall and gives firmness to the wall (Gama et al., 2015).

The reason for increase in pectin content during development stages might be due to less interaction between the pectin and the other cellular components and as a result the pectin was more available for extraction. On the other hand, decrease during ripening might be due to the degradation of pectin under the action of pecticenzymes, such as polygalacturonase (PG), pectin methyl esterase (PME) or pectatelyase (PL) (Paniagua et al., 2017).

The expression trend of PME is also verified with the pectin content of the cultivars which is higher at unripe stage and decreases with ripening in all cultivars (Table 3). The results were in agreement with the studies of Castillo-Israel et al. (2015) who reported the similar variations during development and ripening of the banana. The increase of pectin content up to a certain stage and then decrease was also observed by Szymańska-Chargot et al. (2016).

The results were in complete agreement with Verma et al. (2014). They studied the expression of PME in G-Naine cultivar of banana and also determined Pectin content during ripening in banana and concluded that total pectin content was decreased during ripening which showed the solubilization of pectin by PME

\subsection{Pectin Content decreases during development and ripening stages}

Pectin of the pulp in all the cultivars (Table 3) showed an increasing trend during the development stages and decreasing trend during the ripening stages. The highest pectin content was observed at stage 6 in all the cultivars. At this stage, highest pectin was found in Basrai (0.36\%) and the lowest in G-Naine $(0.30 \%)$. After stage 6 , during the ripening stages, pectin content decreased in all the cultivars and attained lowest value at $11^{\text {th }}$ stage. The lowest pectin at $11^{\text {th }}$ stage was found in Pisang $(0.09 \%)$ and highest in Brazilian (0.14\%).

Statistical analysis showed a significant difference in pectin content among the stages and among the cultivars also. In William,

Table 2. Visual scoring of Pectin esterase gene expression in different banana cultivars.

\begin{tabular}{|c|c|c|c|c|c|}
\hline Stages & William & Basrai & Gnaine & Brazillian & Pisang \\
\hline 1 & - & - & & & \\
\hline 2 & - & - & & & \\
\hline 3 & - & - & & & \\
\hline 4 & +++ & ++++ & ++++ & +++ & ++ \\
\hline 5 & +++ & ++++ & ++++ & +++ & ++ \\
\hline 6 & +++ & ++++ & ++++ & +++ & ++ \\
\hline 7 & +++ & ++++ & ++++ & +++ & +++ \\
\hline 8 & ++++ & ++++ & ++++ & ++++ & +++ \\
\hline 9 & ++++ & ++++ & ++++ & ++++ & +++ \\
\hline 10 & ++++ & ++++ & +++++ & ++++ & ++++ \\
\hline 11 & +++++ & +++++ & +++++ & +++++ & ++++ \\
\hline
\end{tabular}

+ very low expression, ++ low expression, +++ medium expression, ++++ Strong expression, +++++ very strong expression.

Table 3. Pectin content of the pulp during different stages of development and ripening.

\begin{tabular}{|c|c|c|c|c|c|c|c|c|c|c|c|}
\hline \multirow[t]{2}{*}{ Cultivar } & \multicolumn{11}{|c|}{ Stages of development and ripening } \\
\hline & 1 & 2 & 3 & 4 & 5 & 6 & 7 & 8 & 9 & 10 & 11 \\
\hline William & $\begin{array}{c}0.21 \pm \\
0.01 \text { wxyz }\end{array}$ & $\begin{array}{c}0.24 \pm \\
0.01 \text { tuvw }\end{array}$ & $\begin{array}{c}0.27 \pm \\
0.02 \text { qrst }\end{array}$ & $\begin{array}{c}0.29 \pm \\
0.01 \text { opqr }\end{array}$ & $\begin{array}{c}0.31 \pm \\
0.01 \text { nop }\end{array}$ & $\begin{array}{c}0.35 \pm \\
0.02 \mathrm{~m}\end{array}$ & $\begin{array}{l}0.30 \pm \\
0.04 \mathrm{ij}\end{array}$ & $\begin{array}{l}0.26 \pm \\
0.02 \mathrm{~h}\end{array}$ & $\begin{array}{l}0.19 \pm \\
0.01 \mathrm{fg}\end{array}$ & $\begin{array}{c}0.16 \pm \\
0.02 \text { de }\end{array}$ & $\begin{array}{c}0.111 \pm \\
0.01 \mathrm{c}\end{array}$ \\
\hline G-Naine & $\begin{array}{l}0.18 \pm \\
0.01 \mathrm{z}\end{array}$ & $\begin{array}{c}0.20 \pm \\
0.02 x y z\end{array}$ & $\begin{array}{c}0.23 \pm \\
0.03 \text { uvwx }\end{array}$ & $\begin{array}{c}0.26 \pm \\
0.02 \text { rstu }\end{array}$ & $\begin{array}{c}0.28 \pm \\
0.01 \text { pqrs }\end{array}$ & $\begin{array}{c}0.30 \pm \\
0.03 \text { nopq }\end{array}$ & $\begin{array}{c}0.31 \pm \\
0.011\end{array}$ & $\begin{array}{l}0.25 \pm \\
0.02 \mathrm{hi}\end{array}$ & $\begin{array}{l}0.21 \pm \\
0.01 \mathrm{~g}\end{array}$ & $\begin{array}{l}0.17 \pm \\
0.02 \mathrm{e}\end{array}$ & $\begin{array}{c}0.12 \pm \\
0.02 \mathrm{~cd}\end{array}$ \\
\hline Pisang & $\begin{array}{c}0.19 \pm \\
0.01 \mathrm{yz}\end{array}$ & $\begin{array}{c}0.22 \pm \\
0.01 \text { vwxy }\end{array}$ & $\begin{array}{c}0.24 \pm \\
0.01 \text { tuvw }\end{array}$ & $\begin{array}{c}0.27 \pm \\
0.01 \text { qrst }\end{array}$ & $\begin{array}{c}0.29 \pm \\
0.01 \text { opqr }\end{array}$ & $\begin{array}{c}0.31 \pm \\
0.02 \text { nop }\end{array}$ & $\begin{array}{l}0.29 \pm \\
0.03 \mathrm{k}\end{array}$ & $\begin{array}{l}0.24 \pm \\
0.02 \mathrm{~h}\end{array}$ & $\begin{array}{l}0.20 \pm \\
0.01 \mathrm{fg}\end{array}$ & $\begin{array}{l}0.15 \pm \\
0.03 \mathrm{e}\end{array}$ & $\begin{array}{l}0.99 \pm \\
0.01 \mathrm{c}\end{array}$ \\
\hline Brazilian & $\begin{array}{c}0.22 \pm \\
0.02 \text { vwxy }\end{array}$ & $\begin{array}{c}0.25 \pm \\
0.01 \text { stuv }\end{array}$ & $\begin{array}{c}0.27 \pm \\
0.01 \text { qrst }\end{array}$ & $\begin{array}{c}0.29 \pm \\
0.02 \text { opqr }\end{array}$ & $\begin{array}{c}0.32 \pm \\
0.01 \text { mno }\end{array}$ & $\begin{array}{c}0.34 \pm \\
0.01 \mathrm{~m}\end{array}$ & $\begin{array}{l}0.32 \pm \\
0.02 \mathrm{hi}\end{array}$ & $\begin{array}{l}0.26 \pm \\
0.02 \mathrm{~h}\end{array}$ & $\begin{array}{l}0.22 \pm \\
0.02 \mathrm{f}\end{array}$ & $\begin{array}{c}0.18 \pm \\
0.01 \text { de }\end{array}$ & $\begin{array}{l}0.14 \pm \\
0.04 b\end{array}$ \\
\hline Basrai & $\begin{array}{c}0.20 \pm \\
0.03 \text { xyz }\end{array}$ & $\begin{array}{c}0.23 \pm \\
0.0 \text { uvwx }\end{array}$ & $\begin{array}{c}0.25 \pm \\
0.01 \text { stuv }\end{array}$ & $\begin{array}{c}0.28 \pm \\
0.03 \text { pqrs }\end{array}$ & $\begin{array}{c}0.30 \pm \\
0.05 \text { nopq }\end{array}$ & $\begin{array}{c}0.36 \pm \\
0.01 \mathrm{mn}\end{array}$ & $\begin{array}{l}0.31 \pm \\
0.02 \mathrm{jk}\end{array}$ & $\begin{array}{l}0.27 \pm \\
0.01 \mathrm{hi}\end{array}$ & $\begin{array}{l}0.23 \pm \\
0.03 \mathrm{fg}\end{array}$ & $\begin{array}{l}0.18 \pm \\
0.01 \mathrm{c}\end{array}$ & $\begin{array}{l}0.13 \pm \\
0.05 a\end{array}$ \\
\hline
\end{tabular}

a-z Values with different letters are significant $(\mathrm{P}<0.05)$ from each other; \pm Standard deviation. 
pectin content was $0.21 \%$ at stage 1 and increased upto $0.35 \%$ at stage 6 and then dropped to $0.11 \%$ at stage 11 . Pectin content of G-Naine was $0.18 \%$ at stage 1 and increased to $0.30 \%$ at stage 6 and decreased to $0.12 \%$ at stage 11 . In pisang, pectin content was increased from $0.19 \%$ to $0.31 \%$ from stage 1 to stage 6 and then decreased to $0.09 \%$ at stage 11 .

At stage 1 , pectin content of Brazilian was $0.22 \%$ which increased to $0.32 \%$ at stage 6 and then dropped to $0.14 \%$ at stage 11. In Basrai, pectin content was increased from $0.20 \%$ at stage 1 to $0.31 \%$ at stage 6 and dropped to $0.13 \%$ at stage 11 . The reason for increase in pectin content during development stages might be due to less interaction between the pectin and the other cellular components and as a result the pectin was more available for extraction.

On the other hand, decrease during ripening might be due to the degradation of pectin under the action of pecticenzymes, such as polygalacturonase (PG), pectin methyl esterase (PME) or pectatelyase (PL) (Khawas et al., 2014). The interconversion of pectic substance is presumed to be involved in the characteristic softening which occurs during fruit ripening (Tapre \& Jain, 2012). The results were in agreement with the studies of Castillo-Israel et al. (2015) who reported the similar variations during development and ripening of the banana. The increase of pectin content up to a certain stage and then decrease was also observed by Szymańska-Chargot et al. (2016).

\section{Conclusion}

It can be concluded from this study that pectin esterase gene has a variable expression during development and ripening of the banana fruit in selected cultivars. The expression is mostly increases as development and ripening progressed. Pectin is found highest in early stages of development and then decreases. It can be concluded here that high expression of the pectin esterase gene could result in decreased pectin content. It is recommended for biotechnology researchers to study more on pectin esterase gene in order to manipulate the gene expression to get more pectin even during ripening stages. This study recommends food industry to use banana fruit from early development stage to get more pectin. The study also recommends to use banana to obtain pectin which otherwise is an ignored fruit in early development stages. The study also recommends food scientists/researchers to check the utilization, processing potential and acceptability of pectin from these cultivars of banana in food processing.

\section{References}

Castillo-Israel, K. A. T., Baguio, S. F., Diasanta, M. D. B., Lizardo, R. C. M., Dizon, E. I., \& Mejico, M. I. F. (2015). Extraction and characterization of pectin from Saba banana [Musa'saba'(Musa acuminata $\mathrm{x}$ Musa balbisiana)] peel wastes: a preliminary study. International Food Research Journal, 22(1)
Gama, B., Silva, C. D. F., Silva, L. O., \& Abud, A. K. S. (2015). Extraction and characterization of pectin from citric waste. Chemical Engineering Transactions, 44, 259-264.

Khawas, P., Das, A. J., Dash, K. K., \& Deka, S. C. (2014). Thin-layer drying characteristics of Kachkal banana peel (Musa ABB) of Assam, India. International Food Research Journal, 21(3)

Kohli, P., Kalia, M., \& Gupta, R. (2015). Pectin methylesterases: a review. Journal of Bioprocessing \& Biotechniques, 5(5), 1.

Li, S., Chen, K., \& Grierson, D. (2019). A critical evaluation of the role of ethylene and MADS transcription factors in the network controlling fleshy fruit ripening. The New Phytologist, 221(4), 1724-1741. http:// dx.doi.org/10.1111/nph.15545. PMid:30328615.

Liu, M., Gomes, B. L., Mila, I., Purgatto, E., Peres, L. E., Frasse, P., Maza, E., Zouine, M., Roustan, J. P., Bouzayen, M., \& Pirrello, J. (2016). Comprehensive profiling of ethylene response factor expression identifies ripening-associated ERF genes and their link to key regulators of fruit ripening in tomato. Plant Physiology, 170(3), 1732-1744. http://dx.doi.org/10.1104/pp.15.01859. PMid:26739234.

Ngouémazong, E. D., Christiaens, S., Shpigelman, A., Van Loey, A., \& Hendrickx, M. (2015). The emulsifying and emulsion-stabilizing properties of pectin: A review. Comprehensive Reviews in Food Science and Food Safety, 14(6), 705-718. http://dx.doi.org/10.1111/15414337.12160.

Paniagua, C., Santiago-Doménech, N., Kirby, A. R., Gunning, A. P., Morris, V. J., Quesada, M. A., Matas, A. J., \& Mercado, J. A. (2017). Structural changes in cell wall pectins during strawberry fruit development. Plant Physiology and Biochemistry, 118, 55-63. http:// dx.doi.org/10.1016/j.plaphy.2017.06.001. PMid:28618373.

Szymańska-Chargot, M., Chylińska, M., Pieczywek, P. M., Rösch, P., Schmitt, M., Popp, J., \& Zdunek, A. (2016). Raman imaging of changes in the polysaccharides distribution in the cell wall during apple fruit development and senescence. Planta, 243(4), 935-945. http://dx.doi.org/10.1007/s00425-015-2456-4. PMid:26733465.

Tapre, A. R., \& Jain, R. K. (2012). study of advanced maturity stages of banana. International Journal of Advanced Engineering Research and Studies, 1(3), 272-274.

Verma, C., Singh, R. K., \& Mishra, S. (2014). Biochemical characterization of pectin methylesterase from Musa acuminata referring to delayed ripening. Journal of Pharmacy and Biological Sciences, 9(1), 42-47. http://dx.doi.org/10.9790/3008-09134247.

Wan, C. Y., \& Wilkins, T. A. (1994). A modified hot borate method significantly enhances the yield of high-quality RNA from cotton (Gossypium hirsutum L.). Analytical Biochemistry, 223(1), 7-12. http://dx.doi.org/10.1006/abio.1994.1538. PMid:7535022.

Wang, D., Yeats, T. H., Uluisik, S., Rose, J. K., \& Seymour, G. B. (2018). Fruit softening: revisiting the role of pectin. Trends in Plant Science, 23(4), 302-310. http://dx.doi.org/10.1016/j.tplants.2018.01.006. PMid:29429585.

Yao, Y. X., Zhao, L. L., Hao, Y. J., \& Zhai, H. (2005). Effective extraction of total RNA in apple flesh with improved hot borate method. International Journal of Fruit Science, 22:737-740.

Zega, A., \& D'Ovidio, R. (2016). Genome-wide characterization of pectin methyl esterase genes reveals members differentially expressed in tolerant and susceptible wheats in response to Fusarium graminearum. Plant Physiology and Biochemistry, 108, 1-11. http:// dx.doi.org/10.1016/j.plaphy.2016.06.033. PMid:27393991. 